\title{
SELF-CONFIDENCE AND SPEAKING SKILLS OF THE FIRST-YEAR UNDERGRADUATES: A CORRELATIONAL STUDY AT A PUBLIC SECTOR UNIVERSITY IN PAKISTAN
}

\author{
Kamran Akhtar SIDDIQUI, Rifat Abbas KHAN, Iqra Akhtar SIDDIQUI \\ Sukkur IBA University, Pakistan \\ E-mail: kamran.akhtar@iba-suk.edu.pk; riffatabbas@iba-suk.edu.pk; iqra.beds19@iba-suk.edu.pk
}

\begin{abstract}
All the four language skills: reading, writing, speaking and listening are equally important for language learners. Studies show that students learning English as a second language face challenges in learning these four skills. However, production skills i.e., writing and speaking seem to pose greater challenge to learners especially in non-English countries. The challenges related to speaking might be related to several psychological or environmental factors. Selfconfidence is one of those areas of concern. Therefore, the present study aims to find out if there is a correlation between selfconfidence and speaking grades of first year university students at a public sector university in Pakistan. In this regard, a selfconfidence questionnaire (SCQ) was administered to 31 participants from a class of Business Administration department. The collected data was analysed using the Statistical Package for the Social Sciences (SPSS) 20.0 software and Pearson productmoment correlation coefficient was calculated. The data analysis revealed that there is a positive but statistically nonsignificant correlation between self-confidence and speaking grades. Therefore, the study suggests that some experimental studies on the subject should be conducted, and more variables could be brough in to obtain a broader picture of the phenomenon. Small sample size stands as a limitation of the study.
\end{abstract}

KEYWORDS: Correlation, Self-confidence, Speaking skill, Undergraduates, Pakistan.

\section{Introduction}

Speaking, listening, writing, and reading are the four basic language skills, which are extremely important in everyday life and are indispensable tools for communication (Darcy, Ewert, \& Lidster, 2012, p. 94). As a productive skill, speaking skill poses many obstacles "such as psychological, physiological, and attitudinal" (Gurler, 2015, p.15). The ones which are related to psychology and attitude are internal, while others are external like physical health, the physical environment, and systematic disorders. Under the dual heading of psychological and attitudinal disorders, people think that a lack of self-confidence hinders learners' speech not only in a foreign language but also in their mother-tongue. Studies (de Saint Léger, 2009); McIntyre (2004) point out that self-perception or trust in oneself greatly facilitates the ability of the learners to engage in learning a foreign language (p. 150). A high degree of self-confidence is required for speaking which includes ensuring that someone is speaking without feeling shy and being aggressive in a social setting. Therefore, self-confidence is one of the key elements to overcoming certain significant obstacles so that one can become a native-like speaker of a foreign language such as English. A review of the existing English Language Teaching (ELFT) research reveals that the language skills and their teaching methods have been studied a lot. And from previous literature, it can be inferred that oral speech is closely linked to the psychological and attitudinal facts which make up the inner world of the learner (Gursen Otacioglu, 2008, p. 919). Despite the fact that speaking necessitates physiological and environmental/physical adaptability, this study classifies the literature in speaking skill and self-confidence.Self-confidence can be defined as a person's recognition of one's abilities, love of oneself and awareness of one's emotions (Feltz, 2007). Akagündüz (2006)'s division of self-confidence into two subcategories is as follows: inner selfconfidence and external self-confidence. Continuing with his explanation he said that inner selfconfidence is about individual reconciliation or satisfaction with their own thoughts and emotions. Internal confidence comprises self-esteem, self-love, self-knowledge, concise target declarations, and constructive thought. External self-confidence is the way and mindset toward others, too. Outside selfconfidence aspect is contact and emotion regulation. In Akın (2007)'s study of the self-confidence using self-confidence scale, two factors, both external and internal self-confidence, were identified. Similarly, in their study, Şar, Avcu, and Işıklar (2010) discovered these two elements pertaining to selfconfidence and described them as follows: "Self-confidence can be divided into internal confidence and external confidence" (p. 1205). Elements that shape inner self-confidence include self-love, selfknowledge, consistent goal setting, and positive thought. Inner self-confidence reflects the thoughts and 
emotions of a person; it demonstrates the happiness of one person with oneself and the degree of peace in oneself. The factor that makes up self-confidence is the ability to communicate and control feelings. Individuals with high internal self-confidence are satisfied with themselves and have high self-esteem.

Since English does play an important role in society and has to do with our country from a historical or governmental viewpoint, there are a large number of conversational and other spoken language textbooks in Pakistan. However, English is only used in the classrooms in EFL countries such as Pakistan and students rarely get opportunities to practice English outside classrooms. Since the opportunities to practice a foreign language are very few, students hesitate to speak English. Since English is considered the key to a good job in Pakistan, Pakistani students have spared no effort in learning English, especially speaking skills. However, students have been studying English for many years, but because of many factors, they still cannot make their speech fluent (Ahmed, Pathan, \& Khan, 2017, p. 102). Hasan and Ahmed (2015) conducted a study in Pakistan on the challenges faced by intermediate English language learners in communication. Based on quantitative data, the researchers concluded that the dominant mother tongue, the low quality of English teachers, the students' negative attitude towards spoken English, the incorrect use of methods to enhance spoken English, the inability to use teaching media, the audio-visual aids, and other facilities, are few of the cause of poor communication between students in English (p. 109). Likewise, according to the qualitative findings of Khumalo and Mji (2014), poor infrastructure and lack of basic facilities hinder the teaching and learning process in South Africa, too (p. 1526). Apart from the external constraints in Pakistan, teachers' speaking standards are not high enough in teacher education programs (Bilal, Rehman, Rashid, Adnan, \& Abbas, 2013, p. 435). Hence, many junior or high school graduates, even beginners, cannot speak a foreign language despite years of study. Only scholars can comprehend what they are hearing. Therefore, the existing system of education has created students who cannot listen, speak a foreign language and express themselves (Siddiqui, Syed, \& Sahito, 2021, p. 17). Strangely enough, Latham (2005) presented an assessment that, even in the UK, "the advanced nature of oral use is often limited by a lack of opportunities for teachers to give students long speeches, participate in role-playing and similar activities" (p. 63). In her study, she noted that there was a general lack of structure informing the institutional context of speech and listening. Different research studies (Gursen Otacioglu, 2008; Laird, 2005) have found a substantial correlation between self-confidence and success. Hanton, Mellalieu, and Hall (2004) conducted a qualitative study to see how low self-confidence affects performance. They also derived few sentences from one of the interview respondents: "If selfconfidence is low, then we begin to go pessimistic, which is very counterproductive to performance." (p. 481). Another quote from the same research shows the high degree of self-confidence: "Having a high level of self-assurance boosts the intensity of the emotions and moods you can regulate... You can manage your thinking if you are confident..." (p. 481). The speaking skill has become a matter of extreme concern in the EFL setting with the advancement of technology and communication, increasing opportunities for tour and travel, and the elimination of borders between countries. Self-confidence makes it easier to talk and communicate in both the mother-tongue and the target language, and is, therefore, increasingly important, particularly for oral communication. Hence, taking all of the above things into account, the aim of this study is to see if there is a link between self-confidence and the speaking skills among first-year undergraduates at a Pakistani public institution. In short, the present study tends to answer to the following question:

\section{Research Question}

What is the relationship between first-year undergraduates' self-confidence and speaking skills at a Pakistani public sector university?

\section{Null Hypothesis}

There is a significant correlation between self-confidence and the speaking skill of first-year undergraduates. 


\section{Methodology}

This part of the article explains the research design, the sampling and participants of the study, the data collection tools, their procedure, and data analysis.

\subsection{Research design}

A correlation study design was used for this study because it checks the relation between two different variables. According to Curtis, Comiskey, and Dempsey (2016) and Fraenkel, Wallen, and Hyun (2011), the correlational design measures two or more quantitative variables with two or more features and then calculates the correlation between their features. Likewise, Tekbiyik (2014) states that if the study's aim is not to manipulate variables with claims, as done in laboratory designs, but rather to establish their relationships, then this analysis is called the correlational study. According to McMillan and Schumacher (2010), correlation studies are divided into three sub-headings, namely, twovariable correlation studies, predictive studies, and multi-correlation studies. Since the correlation analysis has two aims, such as describing essential human actions or events (explanations) or forecasting future outcomes (predictions), this research aims to understand whether the variables mentioned in the literature review have any association.

\subsection{Sampling and Participants}

For choosing participants for the analysis a basic random sampling approach was used which means that the likelihood of every case in the sample being included in the sample is equal (Taherdoost, 2016). The participants in the study were 31 students who volunteered to participate in the research. Participants came from a Business Studies class. All the 31 students filled the questionnaire out of which 10 were females and 21 males.

\subsection{Data Collection Tools and Procedure}

A five-point Liker scale containing 33 elements was used to gather cross-sectional data about the level of self-confidence of the participants. The scale is called the Self-confidence Questionnaire (SCQ) which Akın (2007) developed. It was administered to the participants of the study using Google forms. The SCQ has no negative items, and the highest points show a high level of self-confidence. The reliability for the SCQ has been 0.83 which indicates that the scale has a high level of reliability (Eraydin \& Karagözoğlu, 2017). Despite this fact, the tool was checked for reliability in the context of the study. The Cronbach Alpha was .889 which shows that the tool was reliable for the context of this study. The questionnaire also describes the participants' descriptive information and their scores in speaking activities such as presentations. Students were required to report speaking scores of semester 01 and in which they performed a lot of speaking during their Functional English course. Typically, by testing them within the context of vocabulary skills, fluency, consistency, and meaning, the course teacher offers speech scores on presentations or activities. The students reported how many marks they earned out of 10 .

\subsection{Data Analysis}

Tekbiyık (2014) opines that data must be collected at the same time in correlational studies. As a result, questionnaires were collected from the students on the day. Statistical analysis was done with the aid of a statistical program known as SPSS 20.0. According to Tekbiylk (2014), when analysing the level of association between independent and other variables, a Pearson-related analysis is recommended. As a result, the association between self-confidence and speaking ability was investigated using Pearson's moment correlation coefficients.

\section{Findings}

Based on the data analysis, some descriptive information was collected the result of which are given in Table 1 below.

Table 01. Descriptive Statistics

\begin{tabular}{|l|l|l|l|}
\hline & $\mathrm{N}$ & Mean & Std. Deviation \\
\hline Speaking Grades & 31 & 8.0968 & .78972 \\
Self-confidence & 31 & 4.0215 & .40438 \\
Valid N (listwise) & 31 & & \\
\hline
\end{tabular}


Given the above-mentioned descriptive statistics, the average and standard deviation of speaking grades and the degree of self-confidence of all participants were figured out from a total of 31 participants.

3.1 Relationship between self-confidence and speaking skill of the Undergraduates

As a result, Pearson's product-moment correlation coefficient analysis was used to assess the relationship between self-confidence and speaking grades achievement. The results of this association are listed in Table 02 below.

Table 02. Correlations

\begin{tabular}{|ll|l|l|}
\hline & & SG & self-confidence \\
\hline SG & Pearson Correlation & 1 & .034 \\
& Sig. (2-tailed) & & .854 \\
N & 31 & 31 \\
\hline self-confidence & Pearson Correlation & .034 & 1 \\
& Sig. (2-tailed) & .854 & \\
N & 31 & 31 \\
\hline
\end{tabular}

Table 02 shows positive but statistically not significant correlation between self-confidence and speaking scores at .034. The strength of the correlation is very weak because, according to Cohen (1998, pp. 79-81) if $r=.10$ to .29 , the strength of the correlation is weak. In this case, the $r$ value less than .10. This can be explained by the expectation that the students' speaking performance will barely improve if their level of self-confidence improves. Hence, The Pearson correlation between selfconfidence level and speaking grades is determined $(r=.034, p>.01)$. As a result, the Null Hypothesis is rejected because the $p$ value does not meet the significance level. In fact, there is very slight indication of positive relationship between self-confidence and speaking skills among freshmen at a Pakistani public university.

\section{Discussion and Conclusion}

This study aims to find a relationship between self-confidence and speaking grades of first-year students of a public sector university in Pakistan. According to the findings of this study, the link between self-confidence and speaking ability was very slightly significant. Participants who understood their abilities, loved themselves, or were aware of their emotions performed better and scored higher than those who did not want to communicate and suffered from lack of confidence as is reported by McIntyre (2004). According to Şar, Avcu, and Işıklar (2010), that positive correlation gives successful communication skills to the individual who constitutes self-confidence, particularly when speaking. It has been an important concern not only in Pakistan (Ahmed et al., 2017) but also in other countries (Gan, 2012) such as the United Kingdom (Latham, 2005). This issue is seen to be remedied by instilling reasonable personal self-assurance. The favourable connections revealed in this study are in line with the findings of earlier research studies in the field, such as self-confidence and success (Gursen Otacioglu, 2008), self-confidence and performance (Hanton et al., 2004). Given the nature of the relevant research, some experimental studies can be carried out to improve the level of self-confidence or oral achievement of the findings of the study.

\section{Limitations of the study and Directions for Future Research}

The researchers did not adjust for several insignificant variables, such as individual variances in instructor ratings and their unique grading methods, despite the fact that the study found a slightly positive association between self-confidence and speaking ability. Different assessment techniques for different teachers can be considered. This stands as the limitation of the study. Moreover, this study was conducted on one class of business studies. The scope of the research should be expanded for more useful results. Future research studies should focus on special learning exercises or assignments that need to be changed or coordinated to develop a reasonable degree of self-confidence and speaking capacity.

\section{REFERENCES:}


Ahmed, N., Pathan, Z. H., \& Khan, F. S. (2017)

Akagündüz, N. (2006)

Akın, A. (2007)

Bilal, H. A., Rehman, A., Rashid, A., Adnan, R., \& Abbas, M. (2013)

Cohen, A. D. (1998)

Curtis, E. A.,

Comiskey, C., \&

Dempsey, O. (2016)

Darcy, I., Ewert, D., \&

Lidster, R. (2012)

De Saint Léger, D.

(2009)

Eraydın, S.,

\&Karagözoğlu, Ș. (2017)

Feltz, D. L. (2007)

Fraenkel, J. R., Wallen, N. E., \& Hyun, H. H.

(2011)

Gan, Z. (2012)

Gurler, I. (2015)

Gursen Otacioglu, S.

(2008)

Hanton, S., Mellalieu, S. D., \& Hall, R. (2004)

Hasan, S., \& Ahmed, M. (2015).

Khumalo, B., \& Mji, A. (2014)

Laird, T. F. N. (2005)

Latham, D. (2005)

McIntyre, D. (2004)

McMillan, J. H.,\&

Schumacher, S. (2010)

Şar, A. H., Avcu, R., \&

Işıklar, A. (2010)

Siddiqui, K. A., Syed, H.,

\& Sahito, Z. (2021)

Taherdoost, H. (2016)

Tekbıyık, A.

(2014)
Exploring the causes of English language speaking anxiety among postgraduate students of the University of Balochistan, Pakistan. // International Journal of English Linguistics, 7(2), p. 99.

İnsan yaşamında özgüven kavramı. İstanbul: Ümraniye Rehberlik ve Araştırma Merkezi Müdürlüğü Yayınları (1).

Öz-Güven ölçeği'nin geliştirilmesi ve psikometrik özellikleri. // Abant İzzet Baysal Üniversitesi Eğitim Fakültesi Dergisi.

Problems in Speaking English with L2 Learners of Rural Area Schools of Pakistan.// Language in India, 13 (10), pp. 1220-1235.

Strategies in learning and using a second language. Harlow: Longman

Importance and use of correlational research. // Nurse Researcher, 23 (6), pp. 20-25.

Bringing pronunciation instruction back into the classroom: An ESL teachers' pronunciation "toolbox". -In: Proceedings of the 3rd Pronunciation in Second Language Learning and Teaching Conference, pp. 93-108.

Self-assessment of speaking skills and participation in a foreign language class. // Foreign Language Annals, 42 (1), pp.158-178.

Investigation of self-compassion, self-confidence and submissive behaviors of nursing students studying in different curriculums. // Nurse education today, 54, pp. 44-50.

Self-confidence and sports performance. -In: D. Smith \& M. Bar-Eli (eds.), Essential readings in sport and exercise psychology. Human Kinetics, pp. 278-294

How to design and evaluate research in education: New York: McGraw-Hill

Humanities/Social Sciences/Languages.

Understanding L2 speaking problems: Implications for ESL curriculum development in a teacher training institution in Hong Kong. // Australian Journal of Teacher Education, 37 (1), p. 3.

Correlation between self-confidence and speaking skill of English language teaching and English language and literature preparatory students. // Curr Res Soc Sci, 1(2), pp. 14-19. Prospective Teachers' Problem Solving Skills and Self-Confidence Levels. // Educational Sciences: Theory and Practice, 8(3), pp. 915-923.

Self-confidence and anxiety interpretation: A qualitative investigation. // Psychology of sport and exercise, 5(4), pp. 477-495.

Issues of English language learners in communication at intermediate level in Pakistan. // Journal of Literature, Languages and Linguistics, 8, pp.104-111.

Exploring educators' perceptions of the impact of poor infrastructure on learning and teaching in rural South African schools. // Mediterranean Journal of Social Sciences, 5 (20), pp. 1521-1521.

College students' experiences with diversity and their effects on academic self-confidence, social agency, and disposition toward critical thinking. // Research in higher education, 46 (4), pp. 365-387.

Speaking, listening and learning: a rationale for the Speaking and Listening Profile. // English in education, 39 (1), pp. 60-74.

Point of view in drama: a socio-pragmatic analysis of Dennis Potter's Brimstone and Treacle. // Language and Literature, 13 (2), pp.139-160.

Research in Education: Evidence-Based Inquiry, MyEducationLab Series. Pearson.

Analyzing undergraduate students' self-confidence levels in terms of some variables. // Procedia-Social and Behavioral Sciences, 5, pp. 1205-1209.

Challenges and strategies of college students in English high school (EMI) classes: a case study. // Educational Forum, (36), pp. 9-25.

Sampling methods in research methodology; how to choose a sampling technique for research. How to Choose a Sampling Technique for Research (April 10, 2016).

İlişkisel araştırma yöntemi. - In:M. Metin (Ed.) Kuramdan uygulamaya eğitimde bilimsel araştırma yöntemleri, pp. 99-114. 